\title{
Design and Implementation of Content Validity: Instrument Development for Evaluating Functional Building Performance
}

\author{
HASNIZAN AKSAH ${ }^{1}$, SUHANA JOHAR ${ }^{1}$, ISMAR MS USMAN ${ }^{1}$, ADI IRFAN CHE ANI ${ }^{1,2}$ \\ ${ }^{1}$ Department of Architecture and Built Environment \\ Faculty of Engineering and Built Environment \\ Universiti Kebangsaan Malaysia, MALAYSIA \\ ${ }^{2}$ School of Liberal Studies \\ Universiti Kebangsaan Malaysia, MALAYSIA
}

\begin{abstract}
The research aim is to critically evaluate the content validity of the functional building performance evaluation criteria using the Content Validity Index (CVI) and modified kappa statistic. The selection of relevant criteria for functional building performance evaluation should be managed effectively by the building management team because it is strongly related to the achievement of organizational objectives and the
\end{abstract}

building occupants' satisfaction. Studies over the past decades have shown that the criteria vary, relying on the intention of conducting the performance evaluation and the types of building. These selection criteria have a direct impact on the functional building performance and need to be done systematically. Thus, the content validity of the functional building performance evaluation criteria is a necessary step in instrument development. To achieve this research aim, the instrument has been developed based on numerous construct items that have been obtained from previous studies by various authors and established rating tools or standards. The sample of the respondents for content validation comprises of seven (7) expert panels in the area of historic building management and building performance evaluation, such as from the local municipality, related government agencies, academician and building management team. The panels reviewed and rated the instrument to ensure its relevance and the representativeness of each item. The result shows that a total of 39 items are valid and are considered to be retained, and will be further tested in the next study. The result has also shown that the Scale level - CVI/ Averaging calculation method (S-CVI/ Ave) for all items has met the criterion of 0.90 . Significantly, content validity should be treated as important because it provides adequate and acceptable items of the content domain.

Key-Words: - Instrument, Content Validity, Functional Building Performance, Historic Government Administrative Buildings.

Received: January 18, 2021. Revised: August 30, 2021. Accepted: September 3, 2021. Published: September 7, 2021.

\section{Introduction}

In the past few decades, building performance is viewed as a concept that is related to the business environment in order to ensure that organizations meet their objectives by focusing on user perception [1]. Similarly, [2] stated building performance is connected to the aims of the building that is designed. Many factors contribute towards the evolution of building performance such as the shifting of building needs and changes in the environment [3].

The building performance criteria need to be identified in order to measure the performance. Several building performance elements and criteria can be involved based on the decision of the organization on the specific purposes of evaluation and the type of building [2][4]. Accordingly, this study is centred on the functional building performance evaluation. The key aspect of functional building performance is the success of the building supports on the organization's objectives and occupant's requirements [1]. Another study has addressed the concerns of functional building performance is on the relation between the building and its occupant, and has focused on the issues of health and safety, communication, image, ergonomics, space and layout [5].

In Malaysia, historic buildings have a high historical significance, aesthetic and cultural values and are regarded as essential in promoting tourism. The types of building comprise government, institutional, residential, commercial, monuments, palaces, etcetera [6]. One of the types of historic government building is the historic government 
administrative building, which is important to be maintained and where evaluation should be done to ensure that it functions as intended.

However, this building is associated with the issues in the functional building performance evaluation. In recent years, the literature has revealed inconsistencies in the elements and criteria for building performance evaluation [7]. This is supported by [8][9] who state that an effective and systematic method to determine and measure the criteria of building performance has not been sufficiently established, and that there is a variety of methodology and approaches that are used in building performance evaluation. Other than that, the literature on performance evaluation of historic buildings is infrequent in current literature [10]. Surprisingly, functional building performance has not yet been extensively studied by researchers.

Other than that, one of the pertinent issues in achieving functional building performance was the restriction by historic statutory and regulations that have an impact on determination in the conservation work of this buildings [11][12]. There are several needs from the building occupants, for example size of space, the arrangement of room and usage that could not be executed [13]. There is also the conflict on energy efficiency and to meet the users' comfort in the building [12].

Therefore, the good selection of determinant criteria is important because it have a direct impact on the performance in the building. The content validity of the functional building performance evaluation instrument should be done to ensure its relevancy. Therefore, this research aims to critically evaluate the content validity of functional building performance evaluation by using CVI and modified kappa statistic $(k)$.

\section{Literature Review}

\subsection{The concept of Building Performance}

A considerable amount of literature has been published on the concept of building performance. It has an important task in expressing the expectation and requirements of the owners and occupants, which are fulfilled by the designers and building operators [3][14]. It is expected to be associated with the organization's objectives and goals that concerned the occupants' comfort and satisfaction.

Hence, the evaluation of the building performance should be done by organizations to ensure that the buildings work effectively. Various methods can be applied to measure the building performance in order to fulfil the building occupants' requirements and satisfaction, this includes the Post Occupancy Evaluation (POE), balanced scorecard approach and metrics of Key Performance Indicators (KPIs). POE is most widely used and has been implemented in the past decades in evaluating a building that can be adapted to a specific purpose [15][16].

\subsection{Functional Building Performance}

Data from several studies on functional building performance evaluation have shown that a number of authors and researchers have arranged various criteria or attributes that are based on the intention of conducting evaluation and type of building. Criteria for measuring functional building performance should be derived from previous precedent research and established rating tools and standards. Building rating tools have been utilized to measure the building performance [17]. Therefore, the criteria that are involved in functional building performance are focused on five (5) main criteria, i.e., space, comfort, aesthetics, amenities and operational management [18], as shown in Table 1.

Table 1. Criteria in Functional Building Performance Evaluation

\begin{tabular}{|c|c|c|}
\hline \multirow[t]{2}{*}{ No } & \multicolumn{2}{|c|}{$\begin{array}{l}\text { Criteria in Functional Building Performance } \\
\text { Evaluation }\end{array}$} \\
\hline & Criteria & Explanation \\
\hline 1 & $\begin{array}{l}\text { Space } \\
{[1][3][5][13]} \\
{[19][20][21][22]} \\
{[23][24][25][26]} \\
{[27][28][29][30]}\end{array}$ & $\begin{array}{l}\text { This criterion refers to the } \\
\text { ability of building to cater } \\
\text { with users capacity and } \\
\text { concerned with the } \\
\text { measured area and size. The } \\
\text { size and layout of space } \\
\text { should also support the } \\
\text { activities taking place in } \\
\text { building and keep save the } \\
\text { occupants. The sub-criteria } \\
\text { involve are size, } \\
\text { relationship, room layout, } \\
\text { adaptability, privacy, } \\
\text { adequacy of signage, } \\
\text { circulation area, access/ } \\
\text { entrance and emergency } \\
\text { exit. }\end{array}$ \\
\hline 2 & $\begin{array}{l}\text { Comfort } \\
{[1][3][5][13]} \\
{[19][20][21][22]} \\
{[23][24][25][26]} \\
{[27][28][29]}\end{array}$ & $\begin{array}{l}\text { This criterion has a positive } \\
\text { impact on well - being and a } \\
\text { state of physical ease and } \\
\text { free from any unpleasant } \\
\text { feeling. The sub-criteria } \\
\text { involve: } \\
\text { ventilation, lighting, noise, } \\
\text { glare, orientation, Building } \\
\text { Related Illness/ Sick } \\
\text { Building Syndrome }\end{array}$ \\
\hline
\end{tabular}




\begin{tabular}{|l|l|l|}
\hline & & (BRI/SBS), Humidity. \\
\hline 3 & $\begin{array}{l}\text { Aesthetics } \\
{[1][13][19][22]} \\
{[27][28]}\end{array}$ & $\begin{array}{l}\text { This criterion focuses on the } \\
\text { design of a building such as } \\
\text { shape, colour or form as a } \\
\text { component of its cultural } \\
\text { value that portray the } \\
\text { intended image of historic } \\
\text { government administrative } \\
\text { buildings to the immediate } \\
\text { environment The sub- } \\
\text { criteria involve are } \\
\text { harmonious, powerful, } \\
\text { iconic, blend, neutral and } \\
\text { material and finishes. }\end{array}$ \\
\hline 4 & $\begin{array}{l}\text { Amenities } \\
{[1][3][5][13]} \\
{[19][20][21][22]} \\
{[23][24][26][27]} \\
{[28][29][30]}\end{array}$ & $\begin{array}{l}\text { This criterion refers to } \\
\text { or facilities of a building or } \\
\text { area that includes toilet, } \\
\text { pantry, prayer room, staff } \\
\text { lounge, ramps and indicators } \\
\text { for the disabled. The sub- } \\
\text { criteria involve are } \\
\text { completeness, capacity, } \\
\text { positioning, ergonomics, } \\
\text { furnish quality, parking and } \\
\text { disable person requirements. }\end{array}$ \\
\hline 5 & $\begin{array}{l}\text { This criterion deals with the } \\
\text { building users requirements } \\
\text { and organization goals and } \\
\text { also to keep equipment and } \\
\text { Management } \\
\text { system operating as } \\
\text { designed or intended. The } \\
\text { sub-criteria involve are book } \\
\text { and space allocation system, } \\
\text { help desks, user support } \\
\text { systems, manuals, training, } \\
\text { information technology, } \\
\text { security, serviceability, } \\
\text { strategic value and life cycle } \\
\text { cost. }\end{array}$ \\
\hline
\end{tabular}

\subsection{Historic Government Administrative Buildings}

The administrative or office building is one of the types of buildings that includes government service buildings and voluntary sector, and also private and commercial offices [31]. The size of administrative and office buildings varies from a small, singleroomed tenancy in a multi-occupancy building to a large building. This administrative building should be designed appropriately to ensure that the people regardless of age, size and disability could work or visit there.

These administrative buildings are the symbol of governmental power and landmark for the tourism sector [32]. They also represent the identity of the society in the country, states, region and district apart from functioning as a place to govern administration matters [33]. A study has identified factors such as social culture, religious belief, colonialism, ethnicity and utilization of technology that influence the design, size and setting of administrative buildings in Malaysia. Other than that, the quality of the architecture of administrative buildings has a significant effect on the building occupants' satisfaction and comfort [34]. Many historic government administrative buildings were built during pre- to post-independence, for example the Sultan Abdul Samad building, Rumah Persekutuan, Penang City Council building, etcetera.

\subsection{Instrument Validation}

Validity is a crucial aspect of the instrument that is applied in research. A primary concern is the development of a new scale of an instrument, which is supposed to provide proof that the instrument is content valid [35]. Supporting this view, [36] have mentioned that the much-debated question is whether the instruments are related to the intended subject of area. This can also be applied to the existing instruments whether they have never been reported or have simply been untested [37].

Validity can be defined as the extent of instrument measures that are intended to measure [37]. Similarly, validity can be interpreted as the capability of an instrument to assess the construct that is developed in a study [36]. The three (3) types of validity that are commonly used in validity are content, criterion-related and construct [37] [38]. Criterion-related and construct validity are tested by using formal statistical procedures.

The definition of content validity can be described as the extent of a scale that has an adequate sample of items to appear for the construct [39]. Lynn [37] has suggested way to quantify content validity by using the CVI. CVI is commonly used to measure the content validity of an instrument that benefited in aspects of understandability, ease of calculation that focuses on the agreement of relevance, and the arrangement of both item and scale measurement [35]. CVI is the most broadly applied, and has been used for many years in the quantification of content validity quantitatively [40]. It can be computed through Item - CVI (I-CVI) and Scale level - CVI (S-CVI) [37][39].

To compare with other statistical method, [41] has suggested way to quantify content validity by using Content Validity Ratio (CVR) [35][42]. The CVR is well recognised to quantify the content experts' consensus using statistical analysis. However, there were some critics in CVR in aspect 
of response process and consensus of panellists [42]. There is confusion related to Lawshe Codes (1Essential; 2-Useful but not essential; 3-Not necessary) [42][43].

\section{Methodology}

\subsection{Methods in Content Validity}

The two (2) stages involve in the content validity process are the development of instrument and judgment [37][44][45]. For stage 1, the design of an instrument is executed through the three (3) steps process that involve the determination of content domain, generation of item, and the construction of instrument. The first step is to determine the content domain of a construct for the instrument. Content domain is the subject matter that is associated with the items that are being evaluated [46]. It can be identified and obtained through literature review on the subject that is being measured, the interviews with the respondents, and through a focus group. Based on accurate and detailed attributes or variables, a comprehensible understanding of its boundaries and measurements can be obtained. The second step is the generation of item that involves the determination of the content domain of the construct. The third step is the construction of instrument that refines and organizes in an appropriate and suitable format and sequences to ensure that the items are collected in a usable form.

For stage 2, judgment evidence was conducted and obtained from the expert panels. This step requires confirmation form the appointed expert panels, stipulating that the instrument has content validity. Determining the appointed expert panels that are involved often depends on the numbers of accessible and agreeable persons that can be identified, and is not based on the population estimation principle [37]. A specific guideline should be complied on the selection of expert panels for the content validity process.

The expert panels are required to rate each scale in order to measure its relevance to the construct. [37] has stated that a minimum of three (3) experts is required, and has suggested that more than 10 is not desirable [39]. Another study has concluded that the desired number of expert panels in content validity process is 5 to 10 [38].

\subsection{Scale}

The scale that is used in instrument should conceptually and mathematically be meaningful. A 4-point scale is desirable because it does not include a middle rating even though a 3- or 5- point rating scale can be considered [37]. By applying a 4-point rating scale, it can provide adequate delineated information to calculate the value of CVI. Various scales can be used but most often the scale is $1=$ not relevant, $2=$ somewhat relevant, $3=$ quite relevant and 4-highly relevant [35][39][44][47][48]. The actual CVI is considered when the items have obtained a rating of 3 or 4 by the experts [37]. For this study, a 4-point rating scale that has been used represents $1=$ not relevant, $2=$ somewhat relevant, 3=quite relevant and 4-highly relevant.

\subsection{Administration Procedure for Content Validity}

This study has utilized two (2) stages of content validation process that involve the development of instruments and judgment. At the first stage of the development of instruments, the 40 initial items have been derived from previous precedent research and established rating tools and standards that evaluate exercises or activities in functional building performance elements. Items were obtained from a narrative review that had mentioned and evaluated the criteria and sub-criteria in the functional building performance evaluation. The five (5) main criteria that are involved are: (1) space: 9 items; (2) comfort: 8 items; (3) aesthetics: 6 items; (4) amenities: 7 items; and (5) operational management: 10 items.

In the second stage, based on the recommendations by the experts in the content validation field, seven (7) expert panels were appointed and invited to review and rate the instrument, as shown in Table 2. As mentioned by [38], 5-10 panels are considered as the desired number in content validity process. Determining the validity of each item and respondent is an important matter to obtain reliable and valid questionnaire analysis results [49]. The specific guidelines and requirements for the selection of the expert panels are:

- Possess five (5) years of experiences or involvements in historic building management or building performance evaluation. This implies that the panels have diversity of skills and experiences for better understanding the field of historic building management, and communicate well with all sorts of different people involved in industry. The panels should also familiar with the thematic domains or concepts in building performance evaluation.

- For academicians, the panel must lead in research and have at least ten (10) publications in historic building management or building 
performance evaluation.

Table 2. Demographics of expert panels

\begin{tabular}{|c|c|c|c|}
\hline \multirow{2}{*}{$\begin{array}{l}\text { Expert } \\
\text { Panels }\end{array}$} & \multicolumn{3}{|c|}{ Demographic } \\
\hline & Position & Organization & Experience \\
\hline 1 & $\begin{array}{l}\text { Senior } \\
\text { Lecturer }\end{array}$ & $\begin{array}{l}\text { Universiti } \\
\text { Teknologi } \\
\text { Mara, Perak } \\
\text { Campus }\end{array}$ & 10 years \\
\hline 2 & $\begin{array}{l}\text { Senior } \\
\text { Lecturer }\end{array}$ & $\begin{array}{l}\text { Universiti } \\
\text { Teknologi } \\
\text { Mara, Shah } \\
\text { Alam Campus }\end{array}$ & 31 years \\
\hline 3 & Curator & $\begin{array}{l}\text { National } \\
\text { Heritage } \\
\text { Department }\end{array}$ & 17 years \\
\hline 4 & Curator & $\begin{array}{l}\text { National } \\
\text { Heritage } \\
\text { Department }\end{array}$ & 20 years \\
\hline 5 & $\begin{array}{l}\text { Senior } \\
\text { Engineer }\end{array}$ & $\begin{array}{l}\text { Public Work } \\
\text { Department }\end{array}$ & 15 years \\
\hline 6 & Architect & $\begin{array}{l}\text { Kuala Lumpur } \\
\text { City Hall }\end{array}$ & 7 years \\
\hline 7 & $\begin{array}{l}\text { Senior } \\
\text { Assistant } \\
\text { Engineer }\end{array}$ & $\begin{array}{l}\text { Pejabat Daerah } \\
\text { Muar }\end{array}$ & 11 years \\
\hline
\end{tabular}

The instruments were self-distributed to the selected expert panels with an introductory cover letter and content validity form. After that, the completed instruments and forms were returned through the same medium or email.

\subsection{Data Analysis}

The CVI for each item is based on the proportion of rating 3 or 4 by the expert panels and the CVI for the entire instrument is based on the proportion of the total items that are considered as content valid [36]. Adopting a similar position, [35] have stated that CVI value can be computed for each item (ICVI) and the entire scale (S-CVI). Researchers have used I-CVI to assist them in revising, removing or replacing items [39].

Meanwhile, there are two (2) methods to calculate the S-CVI, i.e., S-CVI/UA (universal agreement) and S-CVI/Ave (averaging calculation method) for all items on the scale [39]. S-CVI/UA can be described as the proportion of items that have obtained a rating of 3 or 4 that is given by all the expert panels. Besides, S-CVI/Ave can be described as the average of the I-CVI for all items on the scale. But these two (2) methods could lead to different values, therefore it can be confusing and risky to draw a conclusion about the content validity and to adjust for chance agreement. This can be solved by translating the I-CVI into the values of modified kappa statistics $(k)$ [35][49][50].

Thus, [35] have recommended a new way for the content validity, using the modified kappa $(k)$ that adjusts each I-CVI for chance agreement. After calculating the value of I-CVI for all the items, the modified kappa $(k)$ can be computed by applying the value of $p_{c}$ (probability of chance agreement) and ICVI through this equation $k^{*}=\left(\mathrm{I}-\mathrm{CVI}-p_{c}\right) /\left(1-p_{c}\right)$ [35]. The standard that has been used by [35] for the value for each $\mathrm{k}$ is fair $(0.40-0.59)$, good $(0.60-0.74)$ or excellent (>0.74). For example [50][51][52] have applied both CVI and kappa statistics in their studies.

Items with the value of I-CVI lower than 0.78 would be considered for revision. Meanwhile, those items with very low values would be considered for deletion [35]. Any items that have recorded an ICVI of 0.50 or less are removed because this value is considered as unacceptable [38].

[34] have provided suggestions that any I-CVI of 0.78 and higher and S-CVI/Ave of 0.90 and higher, including of robust conceptual framework can be considered as excellent in terms of content validity. On the other hand, recommendations or suggestions from the expert panels can be added without interfering with the judgment of content validity.

\section{Results and Discussion}

The content validity of the functional building performance evaluation instrument was carried out using the CVI process that had been mentioned by [35][37]. The seven (7) expert panels were requested to rate the relevancy of the items using a 4-point scale; recommendation or suggestions from the expert panels can be made in the comment section.

Table 3 shows the I-CVI value for each item that has been stated on the instruments. The calculation of modified kappa statistics $(k)$ was calculated to adjust the chance agreement of the expert panels. Items with the I-CVI value of more than 0.78 and with greater kappa scores were retained. However, items with a value of I-CVI lower than 0.78 should be considered for revision, combination or to be rephrased based on the expert comments.

Table 3. Result of Content Validity

\begin{tabular}{|l|c|c|c|c|}
\hline \multirow{3}{*}{ Items } & \multicolumn{5}{c|}{ Result of content validity } \\
\cline { 2 - 5 } & $\begin{array}{c}\text { Number in } \\
\text { Agreement }\end{array}$ & $\begin{array}{c}I- \\
C V I \\
a\end{array}$ & $k^{b}$ & $\begin{array}{c}\text { Evaluation } \\
c\end{array}$ \\
\hline 1-SPACE & $7 / 7$ & 1.00 & 1.00 & Excellent \\
\hline Size &
\end{tabular}




\begin{tabular}{|c|c|c|c|c|}
\hline Relationship & $6 / 7$ & 0.86 & 0.85 & Excellent \\
\hline Room layout & $7 / 7$ & 1.00 & 1.00 & Excellent \\
\hline Adaptability & $7 / 7$ & 1.00 & 1.00 & Excellent \\
\hline Privacy & $6 / 7$ & 0.86 & 0.85 & Excellent \\
\hline $\begin{array}{l}\text { Adequacy of } \\
\text { signage }\end{array}$ & $6 / 7$ & 0.86 & 0.85 & Excellent \\
\hline Circulation Area & $7 / 7$ & 1.00 & 1.00 & Excellent \\
\hline Access /Entrance & $7 / 7$ & 1.00 & 1.00 & Excellent \\
\hline Emergency Exit & $7 / 7$ & 1.00 & 1.00 & Excellent \\
\hline \multicolumn{5}{|l|}{ 2- COMFORT } \\
\hline Temperature & $6 / 7$ & 0.86 & 0.85 & Excellent \\
\hline Ventilation & $7 / 7$ & 1.00 & 1.00 & Excellent \\
\hline Lighting & $7 / 7$ & 1.00 & 1.00 & Excellent \\
\hline Noise & $5 / 7$ & 0.71 & 0.65 & Good \\
\hline Glare & $5 / 7$ & 0.71 & 0.65 & Good \\
\hline Orientation & $6 / 7$ & 0.86 & 0.85 & Excellent \\
\hline BRI/SBS & $6 / 7$ & 0.86 & 0.85 & Excellent \\
\hline Humidity & $7 / 7$ & 1.00 & 1.00 & Excellent \\
\hline \multicolumn{5}{|l|}{ 3-AESTHETICS } \\
\hline Harmonious & $6 / 7$ & 0.86 & 0.85 & Excellent \\
\hline Powerful & $6 / 7$ & 0.86 & 0.85 & Excellent \\
\hline Iconic & $4 / 7$ & 0.57 & 0.45 & Fair \\
\hline Blend & $6 / 7$ & 0.86 & 0.85 & Excellent \\
\hline Neutral & $4 / 7$ & 0.57 & 0.45 & Fair \\
\hline $\begin{array}{l}\text { Material and } \\
\text { finishes }\end{array}$ & $6 / 7$ & 0.86 & 0.85 & Excellent \\
\hline \multicolumn{5}{|l|}{ 4- AMENITIES } \\
\hline Completeness & $7 / 7$ & 1.00 & 1.00 & Excellent \\
\hline Capacity & $6 / 7$ & 0.86 & 0.85 & Excellent \\
\hline Positioning & $6 / 7$ & 0.86 & 0.85 & Excellent \\
\hline Ergonomics & $6 / 7$ & 0.86 & 0.85 & Excellent \\
\hline Furnish quality & $6 / 7$ & 0.86 & 0.85 & Excellent \\
\hline Parking & $7 / 7$ & 1.00 & 1.00 & Excellent \\
\hline $\begin{array}{l}\text { Disable Person } \\
\text { Requirement } \\
\end{array}$ & $6 / 7$ & 0.86 & 0.85 & Excellent \\
\hline \multicolumn{5}{|l|}{$\begin{array}{l}5 \text { - OPERATIO- } \\
\text { NAL MGT }\end{array}$} \\
\hline $\begin{array}{l}\text { Book and space } \\
\text { allocation system }\end{array}$ & $6 / 7$ & 0.86 & 0.85 & Excellent \\
\hline $\begin{array}{l}\text { User support } \\
\text { system }\end{array}$ & $7 / 7$ & 1.00 & 1.00 & Excellent \\
\hline Help desks & $6 / 7$ & 0.86 & 0.85 & Excellent \\
\hline Manuals & $7 / 7$ & 1.00 & 1.00 & Excellent \\
\hline Training & $6 / 7$ & 0.86 & 0.85 & Excellent \\
\hline $\begin{array}{l}\text { Information } \\
\text { Technology }\end{array}$ & $6 / 7$ & 0.86 & 0.85 & Excellent \\
\hline Security & $7 / 7$ & 1.00 & 1.00 & Excellent \\
\hline Serviceability & $7 / 7$ & 1.00 & 1.00 & Excellent \\
\hline Strategic value & $7 / 7$ & 1.00 & 1.00 & Excellent \\
\hline Life cycle cost & $7 / 7$ & 1.00 & 1.00 & Excellent \\
\hline
\end{tabular}

${ }^{a}$ I-CVI: Item-level Content Validity Index, Number of expert panels rating the item 3 or $4 /$ total number of expert panels ${ }^{\mathrm{b}} k$ : kappa assigning the agreement of relevance, $k=(\mathrm{I}-\mathrm{CVI}-$ $\left.p_{c}\right) /\left(1-p_{c}\right)$, where $p_{c}$ (probability of a chance occurrence) was calculated based $p_{c}=[\mathrm{N} ! / \mathrm{A} !(\mathrm{N}-\mathrm{A}) !]^{*} \cdot 5^{\mathrm{N}}, \mathrm{N}=$ number of expert panels and $\mathrm{A}=$ Number agreeing on good relevance.

${ }^{\mathrm{c}}$ Evaluation criteria for kappa as described by [31]: Fair $=k$ of 0.40 to $0.59 ;$ Good $=k$ of 0.60 to 0.74 and Excellent $=k>0.74$

As a result, a total of 36 items are valid and in excellent kappa statistics rated as recommended by [31]. 17 out of 36 excellent items recorded a high level of $k$ value (1.00). Meanwhile, 19 out of 36 excellent items recorded 0.85 for $k$ value. It indicates that the items have adequate sample of items to appear for the constructs.

Other than that, 2 items are in Good kappa statistics rated and 2 items are in Fair kappa statistics rated. These 4 items could be retained: noise, glare, iconic and neutral, and should be considered for revision, combination or rephrasing based on the expert panels comment. It has been suggested that item iconic be combined as it is redundant with item powerful. Besides, item neutral should be rephrased with item appearance for better understanding by the respondents.

The Table 3 also reveals all items under construct of Space, Amenities and Operational Management are in excellent kappa statistics rated. For space, it focuses on the measured area and size to meet the objectives of organizations and cater the capacity of users [1][53]. It should support the tasks and activities of occupants without compromising the safety in building [54]. Other than that, amenities concern on the facilities and spaces provided for people [55]. It reflects the intended purpose of the building [56]. Meanwhile, operational management is necessary to ensure systems and equipment function and are operating as designed and intended [57]. It synchronously involved with physical assets, functional facilities and organization's resources [56].

Consequently, a total of 39 items are valid and are considered to be retained, where all items will be further tested in the next study. The result has also shown that the S-CVI/ Ave for all the items have met the criterion of 0.90 as have been suggested by [39]. The items strongly represent the content domain of the functional building performance evaluation, as shown in Table 4 .

Table 4 Criteria and items in functional building performance evaluation 


\begin{tabular}{|c|c|c|c|}
\hline \multirow[t]{2}{*}{ No } & \multicolumn{3}{|c|}{ Functional Building Performance } \\
\hline & Criteria & $\begin{array}{l}\text { Nos. } \\
\text { of } \\
\text { items }\end{array}$ & Items \\
\hline 1 & Space & 9 & $\begin{array}{l}\text { Size, relationship, room } \\
\text { layout, adaptability, } \\
\text { privacy, adequacy of } \\
\text { signage, circulation area, } \\
\text { access/ entrance and } \\
\text { emergency exit. }\end{array}$ \\
\hline 2 & Comfort & 8 & $\begin{array}{l}\text { Temperature, ventilation, } \\
\text { lighting, noise, glare, } \\
\text { orientation, Building } \\
\text { Related Illness/ Sick } \\
\text { Building Syndrome } \\
\text { (BRI/SBS), Humidity. }\end{array}$ \\
\hline 3 & Aesthetics & 5 & $\begin{array}{l}\text { Harmonious, powerful, } \\
\text { blend, appearance and } \\
\text { material and finishes. }\end{array}$ \\
\hline 4 & Amenities & 7 & $\begin{array}{l}\text { Completeness, } \\
\text { positioning, ergonocity, } \\
\text { furnish quality, parking } \\
\text { and disable person } \\
\text { requirements. }\end{array}$ \\
\hline 5 & $\begin{array}{l}\text { Operatio- } \\
\text { nal Mgt }\end{array}$ & 10 & $\begin{array}{l}\text { Book and space allocation } \\
\text { system, help desks, user } \\
\text { support systems, manuals, } \\
\text { training, information } \\
\text { technology, security, } \\
\text { serviceability, strategic } \\
\text { value and life cycle cost. }\end{array}$ \\
\hline & Total & $\begin{array}{c}39 \\
\text { items }\end{array}$ & \\
\hline
\end{tabular}

\section{Conclusion}

Content validity should be treated as important because it can be put into good use in the aspect of understandability, agreement on relevance items, the ease to measure and to provide both values for item and scale measurement. The two stages of process that are involved in the content validity process comprises meticulous instrument development and judgment of the items in order to ensure that an excellent instrument is produced. Through the analysis of the content validity of the instrument that is involved in this study, this paper has demonstrated an acceptable and adequate measurement for the functional building performance evaluation of historic government administrative buildings. The pilot test on the final version of the functional building performance evaluation instrument will be carried out to determine the reliability. The instrument will be distributed to the selected respondents once the reliability test is determined.
Several areas for future recommendation of this research are suggested. It is suggested for future studies to focus on other areas of building performance such as process performance, technical performance, environmental performance etcetera. This can assist to analyze the performance of historic government administrative buildings. Other than that, this study can also be applied on other types of buildings such as hospital, educational institutions etc.

\section{References:}

[1] Blyth, A., Gilby, A. and Barlex, M,, Guide to Post Occupancy Evaluation. Higher Education Funding Council for England, 2006.

[2] Gopikrishnan, S. and Topkar, V.M., Attributes and descriptors for building performance evaluation, Housing and Building National Research Centre Journal, 2015, pp.1-6.

[3] Natasha Khalil, Syahrul Nizam Kamaruzzaman and Mohamad Rizal Baharum, A Survey of Performance, Jurnal Teknologi, Vol.75, No.9, 2015, pp. 57-63.

[4] Lavy, S., Garcia, J. and Dixit, M.K., Establishment of KPIs for facility performance measurement: review of literature, Facilities, Vol.28, No.9/10, 2010, pp. 440-464.

[5] Mohd. Fadzil Mat Yasin and Egbu, C.O., Harnessing knowledge management in the process of performance evaluation of facilities in Malaysia: A critical success factor, World Congress 2010, 2010. Available at http://usir.salford.ac.uk/12824/

[6] A. Ghafar Ahmad, Conservation of British Colonial Buildings Built Between 1800 and 1930 in Malaysia, Unpublished thesis, 1993, University of Sheffield. Available at: http://etheses.whiterose.ac.uk/14730/1/252500. pdf.

[7] Izran Sarrazin Mohamad, Performance Criteria and Parameters for Post Occupancy Evaluation of Building Performance, Unpublished thesis, Universiti Teknologi Malaysia, 2010.

[8] Sharpe, T., Innovation for sustainable building design and refurbishment in Scotland, Architectural Science Review, 2013, pp. 127146.

[9] Brien, W.O., Gaetani, I., Carlucci, S., Hoes, P.J. and Hensen, J.L.M., On occupant centric building performance metrics, Building and Environment, Vol. 122, 2017, pp.373-385.

[10] Noraini Hamzah, Weng Lou, E.C., Syahrul Nizam Kamaruzzaman, Phui, F.W., Adi Irfan Che Ani, Muhamad Azry Khoiry, An 
environmental study on development of refurbishment assessment themes for heritage non-domestic buildings in Malaysia, Ekoloji, Vol 28, No. 107, 2019, pp. 3-15.

[11] Siti Norlizaiha Harun, Heritage Building Conservation in Malaysia: Experience and challenges, Procedia Engineering, Vol. 20, 2011, pp.41-53.

[12] Martines, M.A., Tort, A.I., Cho, S. and Vivancos J.L., Energy efficiency and thermal comfort in historic buildings: A review, Renewable and Sustainable Energy Reviews, Vol.61, 2016, pp. 70-85.

[13] Ahmad Ezanee Hashim, Hasnizan Aksah, Shahrul Yani Said, Functional assessment through Post Occupancy Review on Refurbished Historical Public Building in Kuala Lumpur, Procedia Social and Behavioral Science, Vol. 68, 2012, pp. 330340.

[14] Pati, D., Park, C.S. and Augenbroe, G., Roles of building performance assessment in stakeholder dialogue in AEC, Automation in Construction, Vol.15, No.2, 2006, pp. 415427.

[15] Preiser, W.F.E. Post Occupancy Evaluation: How to make buildings work better, Facilities Vol.13, No.11, 1995, pp. 19-28.

[16] Li, P., Froese, T.M. and Brager, G. Postoccupancy evaluation: State-of-the-art analysis and state-of-the-practice review, Building and Environment. Vol.133, 2018, pp. 187-202.

[17] Zuhairuse Md Darus, Nor Atikah Hashim, Elias Salleh, Lim, C.H., Abdul Khalim Abdul Rashid, Siti Nurhidayah Abdul Manan, Development of Rating System for Sustainable Building in Malaysia, WSEAS Transactions on Environment and Development, Vol. 5, No.3, 2009, pp. 260-272.

[18] Hasnizan Aksah, Adi Irfan Che Ani, Siti Hamidah Husain, The development of Conceptual Framework of Functional Building Performance Criteria in Historic Government Buildings, International Journal of Recent Technology and Engineering, Vol.7, No.6S2, 2019, pp. 215-218.

[19] Lai J.H.K. and Man, C. S., Developing a performance evaluation scheme for engineering facilities in commercial buildings: state-of-theart review, International Journal of Strategic Property Management, Vol.21, No.1, 2017, pp. 41-57.

[20] Natasha Khalil, Syahrul Nizam Kamaruzzaman and Mohamad Rizal Baharum, Ranking the indicators of building performance and the users' risk via Analytical Hierarchy Process (AHP): Case of Malaysia, Ecological Indicators. Vol.71, 2016, pp. 567-576.

[21] Okolie, K.C. and Ogunoh, P.E., Assessment of functional and environmental Indicators in the performance of buildings in Federal Universities of South East Nigeria, International Journal and Advanced Technology Studies, Vol.1, No.2, 2013, pp.111.

[22] Vischer, J.C., Applying knowledge on building performance: From evidence to intelligence, Intelligent Buildings International, Vol.1, No.4, 2009, pp. 239-248.

[23] Vischer, J.C., Towards an environmental psychology of workspace: How people are affected by environments for work, Architectural Science Review, Vol.51, No.2, 2008, pp. 97-108.

[24] Preiser, W.F.E. and Schramm, U. Intelligent office building performance evaluation, Facilities, Vol.20, No.7/8, 2002, pp. 279-287.

[25] Carpenter, C.L. and Oloufa, A.A., Post Occupancy Evaluation of Buildings and Development of Facility Performance Criteria, Journal of Architectural Engineering, Vol.1, No.2, 2002, pp. 77-81.

[26] Akman, E., Post Occupancy Evaluation With Building Values Approach, Unpublished Thesis, Bilkent University, 2002.

[27] Szigeti, F. and Davis, G., Functionality and serviceability: Tools for Stating Functional Requirements for evaluating facilities, Learning from our building: A State of the practice summary of POE. National Academy Press, 2001, pp. 65-78.

[28] American Society for Testing and Material, ASTM Standards on Whole Building Functionality and Serviceability, 2nd edition. West Conshohocken, Pennsylvania: ASTM (American Society for Testing and Materials), 2002.

[29] Preiser, W.F.E., The habitability framework: a conceptual approach towards linking human behaviour and physical environment, Design Studies, Vol.4, No.2, 1983, pp. 84-91.

[30] Mohammad A. Hassanain, On the performance evaluation of sustainable student housing facilities, Journal of Facilities Management, Vol.6, No.3, 2008, pp. 212-2225.

[31] Centre for Excellence in Universal Design, Building for everyone: A universal design approach, planning and policy, 2012, pp. 1-96. Available online on www.universaldesign.ie 
[32] Hazrina Haja Bava Mohidin and Alice Sabrina Ismail, Historical development of administration architecture in Malaysia (15th21st century), IOP Conference Series: Earth and Environmental Science, Vol.18, No.1, 2014.

[33] Hazrina Haja Bava Mohidin and Alice Sabrina Ismail, Responsive Design Approach in Modern Malaysian Administrative Building, Procedia - Social and Behavioral Sciences. Vol.153, 2014, pp. 330-340.

[34] Elmahadi, M.A., Mazlan Mohd. Tahir, Surat, M., Norngainy Mohd Tawil and Ismar Minang Satotoy Usman, Effective office environment architecture: Finding ingenious ideas in a home to stimulate the office environment, Procedia Engineering, Vol. 20, 2011, pp. 380-388.

[35] Polit, D.F., Beck, C.T. and Owen, S.V., Focus on Research Methods Is the CVI an Acceptable Indicator of Content Validity? Appraisal and Recommendations, Research in nursing \& health, Vol. 30, 2007, pp. 459-467.

[36] Azwani Masuwai, Nor'ain Mohd Tajudin and Noor Shah Saad, Evaluating the face and content validity of a Teaching and Learning Guiding Principles Instrument (TLGPI): A perspective study of Malaysian teacher educators, Geografia: Malaysian Journal of Society \& Space, Vol.12, No.3, 2016, pp. 1121.

[37] Lynn, M.R., Determination and quantification of content validity, Nursing Research, Vol.35, No.6, 1986, pp.382-386.

[38] Almanasreh, E., Moles, R. and Chen, T.F., Research in Social and Administrative Pharmacy Eval uation of methods used for estimating content validity, Research in Social and Administrative Pharmacy, 2018.

[39] Polit, D.F. and Beck, C.T., The Content Validity Index: Are You Sure You Know What's Being Reported? Critique and Recommendations, Research in nursing \& health, Vol.31, No.4, 2006, pp. 341-354.

[40] Lau, X.C., Wong, Y.L., Wong, J.E., Koh, D., Sedek, R., Jamil, A.T., Ng, A.L.O., Hazizi, A.S., Ruzita A.T. and Poh, B.K., Development and Validation of a Physical Activity Educational Module for Overweight and Obese Adolescents: CERGAS Programme, International journal of environmental research and public health, Vol.16(9), 2019, pp. 1-16.

[41] Lawshe, C.H. A quantitative approach to content validity 1 , Personnel psychology, Vol. 28, No. 4, 1975, pp. 563-575.
[42] Nor Azizah Ahmad, Sulfeeza Mohd. Drus, Hairoldenan Kasim, Assessing Content Validity of Enterprise Architecture Adoption Questionnaire (EAAQ) Among Content Experts, 2019 IEEE $9^{\text {th }}$ Symposium on Computer Applications and Industrial Electronics (ISCAIE), 2019, pp. 160-165, doi: 10.1109/ISCAIE.2019.8743918.

[43] Allahyari, T., Rangi N.H., and Zayeri, F., Development and Evaluation of a New Questionnaire for Rating of Cognitive Failures at Work, International Journal of Occupational Hygiene, Vol. 3, No. 1, 2011, pp. 6- 11.

[44] Noor Hamzani Farizan, Rosnah Sutan and Kulanthayan KC Mani, Development and Validation of a Survey Instrument on Drowning Prevention and Water Safety among Parents of Primary School Children, Journal of Clinical and Diagnostic Research, 2019, pp. 16.

[45] Rodrigues, I.B., Adachi, J.D., Beattie, K.A. and MacDermid, J.C., Development and validation of a new tool to measure the facilitators, barriers and preferences to exercise in people with osteoporosis, BMC Musculoskeletal Disorders, Vol.18, No.1, 2017, pp. 1-9.

[46] Zamanzadeh, V., Ghahramaniam, A., Rassouli, M., Abbaszadeh, A., Alavimajd, H. and Nifankar, A., Design and Implementation Content Validity Study: Development of an instrument for measuring Patient-Centered Communication, Journal of Caring Sciences, Vol.4, No.2, 2015, pp. 165-178.

[47] Emy Salfarina Alias, M. Mukhtar and Ruzzakiah Jenal, Instrument development for measuring the acceptance of UC \& C: A content validity study, International Journal of Advanced Computer Science and Applications, Vol. 10(4), 2019, pp. 187-193.

[48] Zailani Muhamad, Ayiesah Ramli and Salleh Amat, Validity and Reliability of the Clinical Competency Evaluation Instrument for Use among Physiotherapy Students: Pilot study, Sultan Qaboos University Med Journal, Vol. 15(2), 2015, pp. 266-274.

[49] Roshana Takim, Nor Malyana Samsuddin and Abdul Hadi Nawawi, Assessing the content validity of hospital disaster resilience assessment instrument, Jurnal Teknologi, Vol.78, No.5-2, 2016, pp. 35-42.

[50] Kovacic, D., Using the Content Validity Index to Determine Content Validity of an Instrument Assessing Health Care Providers' General Knowledge of Human Trafficking, Journal of 
Human Trafficking. Vol.4, No.4, 2018, pp. 327-335.

[51] Izran Sarrazin Mohammad, Tsau, K, Y. and Rohaya Abdul Jalil, Content Validation of the User Attitudinal Component and factors. International Journal of Built Environment and Sustainability. Vol . 7, No. 1, 2020, pp. 21-35.

[52] Mohamad Tajudin Saidin, Izran Sarrazin Mohamad, Fairiz Miza Yop Zain and Nor Suzila Lop, Establishing the Content Validity Index of Post Occupancy Evaluation (POE) of Green Building in Malaysia, Malaysia Journal of Sustainable Environment, Vol.7, No.1, 2020, pp.75-100.

[53] Then, D.S.S., Tan, T.H., Santovito, R. F. and Jensen, P. A., Attributes of alignment of real estate and facilities management to business needs: An international comparative analysis, Journal of Corporate Real Estate, Vol. 16, No.2, 2014, pp. 80-96. doi:10.1108/JCRE-092013-0026.

[54] Clift, M., Building Quality Assessment (BQA) for offices, Structural Survey, Vol 14, No.2, 1996, pp 22-25.

[55] Palliyaguru, R. S. and Amaratunga, R. D. G., Disaster risk reduction and post disaster infrastructure reconstruction in Sri Lanka, Proceeding of 9th International Postgraduate Research Conference in the Built and Human Environment, 2009, pp. 824-835.

[56] Preiser, W.F.E., Assessing building performance, Oxford: Elsevier ButterworthHeinemann, 2005,doi:10.4324/9780080455228

[57] Lewis, A., Riley, D. \& Elmualim, A., Defining High Performance Buildings for Operations and Maintenance. International journal of Facility Management, Vol. 1 No.2, 2010, pp. 16-22.

\section{Contribution of Individual Authors to the Creation of a Scientific Article (Ghostwriting Policy)}

Hasnizan Aksah wrote the drafts of the main chapter and subchapter, conducted the data collection and analysis.

Suhana Johar and Ismar MS Usman conducted the literary review, formulated the general conclusions, improved the language, and were in charge of formatting and revising the paper.

Adi Irfan Che Ani improved the structure of study, sharpened the analysis, finalisation of the paper and developed the abstract.

\section{Sources of Funding for Research Presented in a Scientific Article or Scientific Article Itself}

The authors would like to acknowledge the academic and financial support of Universiti Teknologi Mara (UiTM) and the Ministry of Higher Education (MOHE), specifically for the Skim Latihan Akademik Bumiputera (SLAB) for funding this research. The authors highly acknowledge the Faculty of Engineering and Built Environment, Universiti Kebangsaan Malaysia via the grant support GGP-2017-028 and TAP-K013189.

\section{Creative Commons Attribution License 4.0 (Attribution 4.0 International, CC BY 4.0)}

This article is published under the terms of the Creative Commons Attribution License 4.0 https://creativecommons.org/licenses/by/4.0/deed.en _US 